\title{
A Case of Fetal Cholelithiasis Related to Maternal Intra- hepatic Cholestasis of Pregnancy
}

Dong Keon Yon, M.D., Jae Woo An, M.D., Ji Hee Kim, M.D., Ji-Hyun Jeon, M.D., and Ju Sun Heo, M.D. Department of Pediatrics, CHA Gangnam Medical Center, CHA University School of Medicine, Seoul, Korea

\section{ABSTRACT}

Despite the improved accuracy and increasing use of prenatal ultrasonography, fetal cholelithiasis is a rarely detected disease, and its natural history and clinical significance are not yet well defined. Many maternal and neonatal risk factors are associated with fetal cholelithiasis. Intrahepatic cholestasis of pregnancy could be a risk factor for fetal cholelithiasis, but no case reports in previous literatures have demonstrated this relationship. We present a case of fetal cholelithiasis in the late third trimester of pregnancy that was related to intrahepatic cholestasis of pregnancy, along with a brief review of associated literatures.

Key Words: Cholelithiasis, Intrahepatic cholestasis of pregnancy, Ultrasonography, Prenatal

서론

최근 산전 초음파 시행 건수의 증가 및 영상 기계의 발달에도 불구하고 태아 담석증은 굉장 히 드문 질환으로 알려져 있으며, 아직까지는 태아 담석증에 대한 원인, 임상적 증상 및 예후 에 대해서 명확히 알려져 있지 않다.

국내에서 보고된 신생아 담석증 증례로 2004년 Shim 등ํㅣ 이 보고한 미숙아 담석증 1례가 있었으나, 이 증례의 경우 생후 88 일째에 담석증이 진단되었으며, 그 유발 원인이 출생 이후 장기간의 금식과 총 정맥영양으로 생각되어 태아 담석증에는 합당하지 않은 소견이다. 그 외 태아 담석증에 대한 국내 보고는 없는 실정이다. 또한 산모의 임신성 간내 담즙정체는 태아 담석증의 가능한 위험 인자로 언급되고 있으나, 국내외적으로 이에 대한 증례 보고는 없다.

우리는 임신 제 3 분기에 산모의 임신성 간내 담즙정체와 동반되어 관찰된 태아 담석증을 경험하였기에 문헌 고찰과 함께 보고하는 바이다.

\section{증례}

산모는 33세 초산부로 체외 수정 시술로 쌍둥이를 임신하였다. 임신기간 중에 음주, 흡 연, 약물 복용력은 없었고 태반 조기 박리, 감염, 임신성 당뇨나 고혈압 등의 질환력도 없었
Received: 2 February 2017

Revised: 19 April 2017

Accepted: 8 May 2017

Correspondence to: Ju Sun Heo

Department of Pediatrics, CHA

Gangnam Medical Center, CHA

University, 566 Nonhyeon-ro,

Gangnam-gu, Seoul 06135, Korea

Tel: + 82-2-3468-2801

Fax: +82-2-3468-2618

E-mail: wnslatjsanf@hanmail.net

Copyright(c)

By Korean Society of Neonatology.

All right reserved.

This is an Open-Access article distributed under the terms of the Creative Commons Attribution Non-Commercial License (http://creativecommons.org/licenses/ by-nc/4.0), which permits unrestricted non-commercial use, distribution, and reproduction in any medium, provided the original work is properly cited. 
다. 외할머니의 고혈압 병력 외에 간질환을 포함한 다른 가족력 은 없었다. 임신 전 체질량지수는 $18.4 \mathrm{~kg} / \mathrm{m}^{2}$ 이었으며, 임신 기 간 중 $20 \mathrm{~kg}$ 의 체중 증가가 있었다. 재태 기간 34 주 무렵부터 전 신의 가려운 증상 시작되었으며 발진은 동반되지 않았다. 이 때 시행한 혈액 검사상 아스파트산 아미노기전달효소(aspartate aminotransferase, AST)/알라닌 아미노기전달효소(alanine aminotransferase, ALT) 39/53 IU/L (참고치 5-40 IU/L), 알칼라 인포스피타제(alkaline phosphatase, ALP) 497 IU/L (참고치 40$250 \mathrm{IU} / \mathrm{L}$ )로 ALT, ALP의 상승 소견 관찰되었고 총 빌리루빈 0.2 $\mathrm{mg} / \mathrm{dL}$ (참고치 0.2-1.2 mg/dL), 감마-글루타밀 전이효소 $41 \mathrm{U} /$ $\mathrm{L}$ (참고치 7-32 U/L), 젓산 탈수소효소 $490 \mathrm{U} / \mathrm{L}$ (참고치 210-435 $\mathrm{U} / \mathrm{L}$ ), 총 콜레스테롤 $188 \mathrm{mg} / \mathrm{dL}$ (참고치 115-230 mg/dL)로 확 인되었다. 또한, 간염 바이러스 표지자 검사에서 B형 간염 표면항 원(hepatitis B surface antigen, HBsAg) 음성, B형 간염 표면항 원에 대한 항체(hepatitis B virus antibody, HBsAb) 양성(639.2 $\mathrm{IU} / \mathrm{L}), \mathrm{C}$ 형 간염 바이러스 항체(Anti-hepatitis C virus antibody) 음성으로 확인되었다. 재태 기간 35주 3일에 시행한 산모의 간 초 음파에서 간, 담낭 내 이상 소견은 관찰되지 않았다. 재태 기간 36 주 1일 시행한 혈액 검사상 AST/ALT/ALP가 73/137/755 IU/L로 더 상승하였고 분만 전날 AST/ALT 179/302 IU/L까지 최고치를 보였다가 분만 2일 뒤 AST/ALT/ALP 59/141/560 IU/L로 감소하 여 분만 10 일 뒤 정상 범위로 회복되는 양상을 보였다. 임신 및 분 만 후 검사에서 총 빌리루빈은 지속적으로 정상 범위였다. 산모는 임상 양상 및 검사 소견을 바탕으로 임신성 간내 담즙정체로 진단

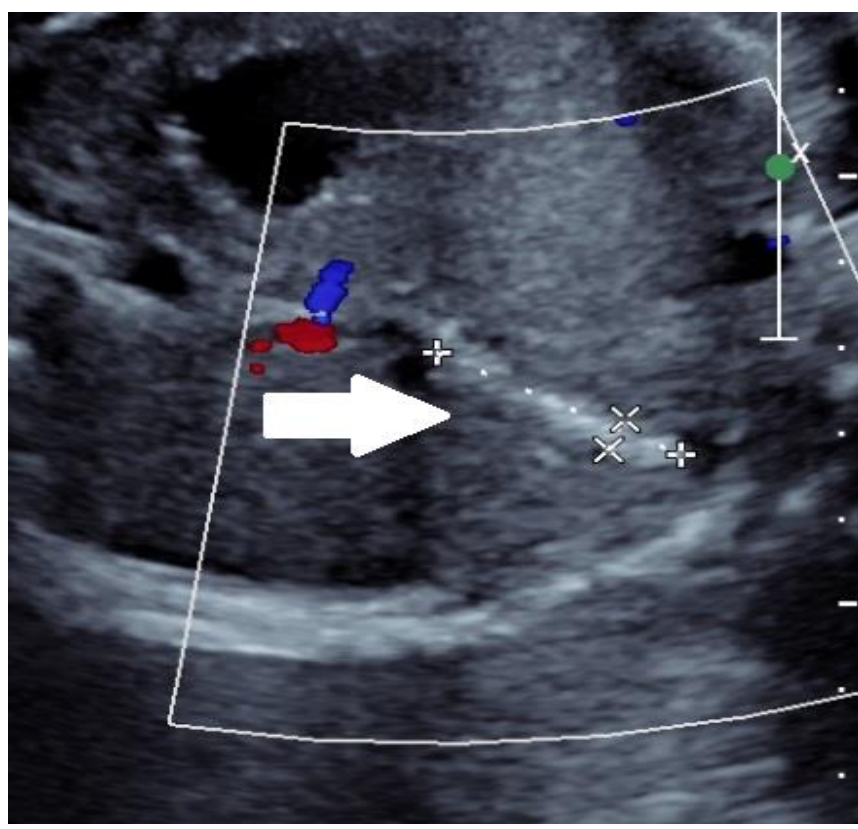

Figure 1. The fetal ultrasonography scan at $35^{+3}$ weeks of gestation shows a $2.8 \times 0.4 \mathrm{~cm}$ hyperechoic gallbladder lesion which may be calcified (arrow).
되었으며, 소양감이 심하지 않아 임신 중 ursodeoxycholic acid 약물 치료는 시행하지 않았다. 정기적인 태아 산전 초음파에서 재 태 기간 32주 1일까지는 특이 소견 관찰되지 않았으나 재태 기간 35 주 3일에 시행한 초음파상 둘째 태아의 담낭 부위에서 $2.8 \times 0.4$ $\mathrm{cm}$ 정도의 고음영 병변이 확인되어, 태아 담석증이 의심되었다 (Figure 1), 간을 포함한 그 외 다른 부위에서는 이상 소견이 관찰 되지 않았다.

환자는 재태 기간 36주 6일에 선택적 제왕절개술로 출생한 쌍 둥이 중 둘째 남아로, 특별한 분만 손상 없이 태어났으며 Apgar 점수는 1분 8점, 5분 9점이었다. 출생 당시 체중은 2,190 g (25-50 백분위수), 신장 $46.5 \mathrm{~cm}$ (25-50백분위수), 두위 $32 \mathrm{~cm}$ (25-50백 분위수)이었고, 활력징후는 정상이었다. 진찰소견상 전신 상태는 양호해 보였고 피부의 황달 소견 없었으며, 청진시 호흡음은 깨끗 하였고, 심잡음은 들리지 않았다. 복부는 부드럽고 장음도 정상이 었으며, 간이나 비장은 촉지되지 않았고, 그 외 촉지되는 종괴도 없었다.

출생 당일 말초혈액 검사상 헤모글로빈 $15.3 \mathrm{~g} / \mathrm{dL}$, 헤마토크릿 43\%, AST 55 IU/L, ALT 8 IU/L, 총 빌리루빈 $1.2 \mathrm{mg} / \mathrm{dL}$, 직접 빌 리루빈 $0.8 \mathrm{mg} / \mathrm{dL}, \mathrm{ALP} 453 \mathrm{IU} / \mathrm{L}$, 총 콜레스테롤 $83 \mathrm{mg} / \mathrm{dL}$ 였다. 혈액형은 $\mathrm{O}, \mathrm{Rh}+($ 산모 $\mathrm{B}, \mathrm{Rh}+$ )였다. 생후 4일째 시행한 검사에 서 총 빌리루빈 $6.2 \mathrm{mg} / \mathrm{dL}$ 로 약간 상승되는 양상 보였으나 AST, ALT, 직접 빌리루빈 수치 정상이었고 ALP는 $399 \mathrm{IU} / \mathrm{L}$ 로 감소하는 양상 보였다. 그 외 선천성 대사 이상, 패혈증, 용혈성 빈혈 등을 시 사하는 소견은 관찰되지 않았다. 생후 2일째 시행한 복부 초음파 검사에서 담낭의 전 부위에서 다수의 음영이 증가된 석회화 소견 이 보여 담석증이 진단되었다(Figure 2A). 담낭벽의 두께 및 크기 는 정상이었으며, 그 외 간, 비장 등에서 이상 소견은 관찰되지 않 았다. 쌍둥이 첫째 남아의 경우, 출생체중 $2,470 \mathrm{~g}$ 으로 출생했으 며, 출생 3 일 째 시행한 복부 초음파 검사에서 간, 담도계의 이상 소견은 관찰되지 않았다.

환자는 입원 기간 중 수유 진행에 문제 없었으며, 체중은 초기 $4.1 \%$ 까지 감소하였다가 그 후 증가하는 양상 보였다. 황달이 심하 지 않아 광선 치료는 시행하지 않았다. 태아 담석증과 연관된 특 별한 증상이 관찰되지 않아 약물 치료 없이 외래에서 경과 관찰하 기로 하고 생후 6 일째 퇴원하였다. 이후 생후 1달째 시행한 복부초 음파 검사에서 담석증이 완전히 호전된 양상을 관찰할 수 있었다 (Figure 2B)

\section{고찰}

1928년 Potter에 의해 신생아 부검을 통한 태아 담석증의 존재 가 처음으로 언급되었지만 ${ }^{2)}$, 산전 초음파를 통해 발견된 태아 담 
석증 증례는 1983 년 처음으로 보고되었다 ${ }^{3)}$. 매년 전세계적으로 많은 산전 초음파가 시행되고 있음에도 불구하고 태아 담석증은 굉장히 드문 질환으로 알려져 있다. Cancho Candela 등에 의한 전향적 연구에 의하면, 9,235명의 태아를 대상으로 한 산전 초음 파에서 태아 담석증의 발병률은 $0.45 \%$ 에 불과했다 ${ }^{4)}$. 지난 1 년을 기준으로 본원에서 출생한 3,005명의 신생아 중 태아 담석증은 단 1명에서 발견되었다.

태아 담석증에 대한 산모의 위험 인자로는 비만, 경구피임제의 사용, 담석증의 가족력, 태반내 출혈, 임신 기간 내의 마약성 진통 제 사용, 유전성 구상 적혈구증, 겸상 적혈구 빈혈증 등이 잘 알려
져 있다 ${ }^{5)}$. 태아의 위험 인자로는 용혈성 빈혈, 거대아, 췌장의 낭성 섬유증, 담즙 정체, 고콜레스테롤혈증, $\mathrm{ABO}$ 혈액형 부적합증, 염 색체 이상이나 심장 혹은 소화기 선천 기형, 프로스타글란딘의 영 향, 산전 백혈병양 반응(prenatal leukemoid reaction) 등이 언급 되고 있다 ${ }^{6}$. 본 증례의 경우 기존에 잘 알려진 이러한 위험 인자는 동반되지 않았다.

임신성 간내 담즙정체의 경우, 태아 담석증의 가능한 위험 인자 로 고려되기는 하지만 ${ }^{7)}$, 현재까지 임신성 간내 담즙정체가 있었 던 산모에게서 태아 담석증이 발견된 것에 대한 증례 보고는 국내 외적으로 없었다. 임신성 간내 담즙정체는 임신 중 발진을 동반하
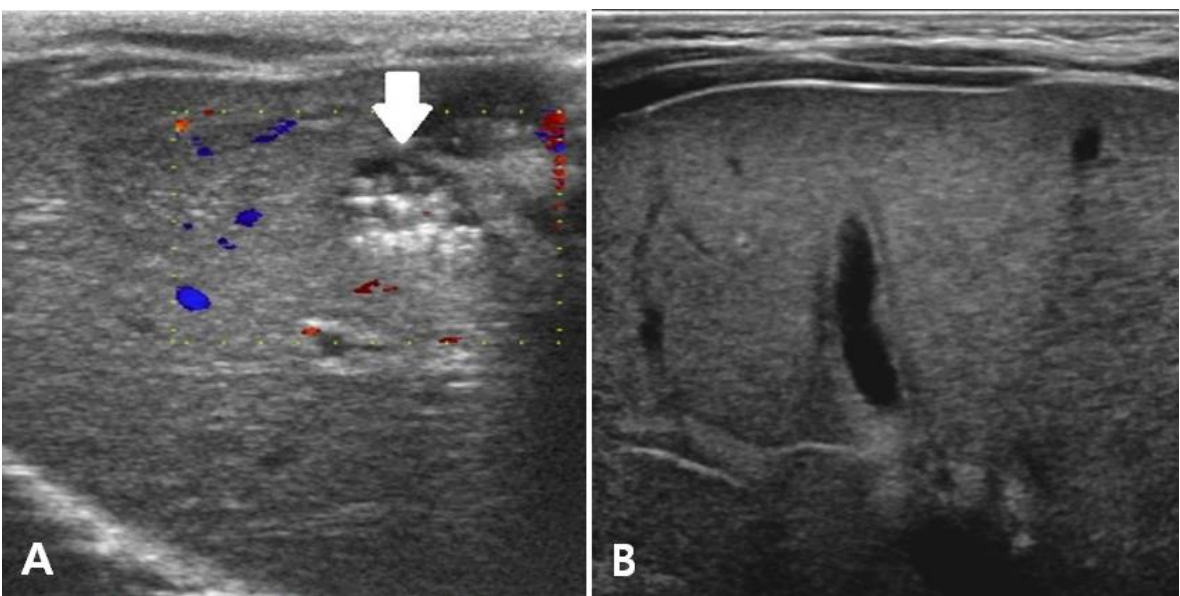

Figure 2. (A) The neonatal abdominal ultrasonography after birth shows echogenic tiny gallbladder stones in entire gallbladder without wall thickening. (B) At postnatal 1 month, the abdominal ultrasonography shows no gallbladder stone.

Table 1. Fetal Characteristics and Neonatal Outcomes of Fetal Cholelithiasis in the Literature Review

\begin{tabular}{|c|c|c|c|c|c|}
\hline Authors & $\begin{array}{l}\text { Patients } \\
\text { (n) }\end{array}$ & $\begin{array}{c}\text { Gestational age } \\
\text { Detected by prenatal } \\
\text { ultrasonography (wks) }\end{array}$ & $\begin{array}{l}\text { Findings and risk } \\
\text { factors associated with } \\
\text { fetal cholelithiasis }\end{array}$ & Treatment & Resolution time \\
\hline Beretsky, et al. ${ }^{3)}$ & 1 & 36 & None & No & Within $1 \mathrm{mo}$ \\
\hline Petrikovsky, et al. ${ }^{15)}$ & 5 & $33-36$ & None & No & Within 12 wks \\
\hline Stringer, et al. ${ }^{16)}$ & 3 & $32-35$ & None & No & Within 6 wks \\
\hline Kiserud, et al. ${ }^{6)}$ & 6 & $33-38$ & 1 with TOF & No & Within 6 wks \\
\hline Nishi, et al. ${ }^{17)}$ & 1 & 34 & None & No & At birth \\
\hline Hertzberg, et al. ${ }^{18)}$ & 2 & $31-36$ & None & No & Within 2 mo \\
\hline Suma, et al. ${ }^{7)}$ & 2 & $30-37$ & None & No & Within 3 mo \\
\hline Cancho Candela, et al. ${ }^{4)}$ & 11 & $29-38$ & None & No & Within 7 wks \\
\hline Munjuluri, et al. ${ }^{19)}$ & 2 & 34 & None & UDCA & Within 4 mo \\
\hline Triunfo, et al. ${ }^{20)}$ & 1 & 35 & None & No & At birth \\
\hline Suhag, et al. ${ }^{5)}$ & 1 & 32 & None & No & Within 2 mo \\
\hline Troyano-Luque, et al. ${ }^{13)}$ & 2 & 26,32 & $\begin{array}{l}1 \text { with maternal Lyme disease } \\
\text { and ceftriaxone use }\end{array}$ & No & $\begin{array}{l}1 \text { persist at } 30 \mathrm{mo}, 1 \\
\text { resolve within } 7 \mathrm{mo}\end{array}$ \\
\hline Yon, et al. (present study) & 1 & 35 & ICP & No & Within 1 mo \\
\hline
\end{tabular}

Abbreviations: ICP, intrahepatic cholestasis of pregnancy; TOF, tetralogy of fallot; UDCA, ursodeoxycholic acid. 
지 않는 가려움증과 함께 혈중 AST, ALT 또는 담즙산의 증가를 특징으로 하며, 경한 황달과 함께 빌리루빈이 증가되는 양상은 약 $10-15 \%$ 의 소수에서만 관찰된다 ${ }^{8,9)}$. 가려움증과 검사상의 이상 소 견은 보통 임신 제 3분기에 시작되며, 분만 이후 수주 이내에 저절 로 호전되는 양상을 보여 본 증례는 임신성 간내 담즙정체에 합 당한 임상 양상을 보인다. 임신성 간내 담즙정체에서 태아 담석증 이 유발될 수 있는 가설로 유전적인 요인과 생식 호르몬 요인을 생각해 볼 수 있다. 유전적 요인과 관련해, 진행성 가족성 간내 담 즙정체증을 유발하는 것으로 알려진, 간담도 전달체인 $A T P 8 B 1$, $A B C B 11, A B C B 4$ 의 동종 또는 이종접합 돌연변이가 있는 경우, 임신성 간내 담즙정체가 더 빈번히 발생하는 것으로 알려져 있다 ${ }^{10,11)}$. 유전적 변이의 종류에 따라 담즙정체의 정도가 다양하게 관 찰될 수 있으며, 이러한 유전적 변이는 신생아 담즙정체 및 청소년 기 담석증 등과도 연관될 수 있다. 생식 호르몬 요인으로 임신성 간내 담즙정체가 주로 발생하는 임신 제 3분기에 에스트로겐의 농도가 가장 높이 올라가는 것을 고려해 볼 수 있다. 17 베타-에 스트라디올에 의해 활성화된 에스트로겐 수용체 알파는 담즙산 수용체로 알려진 farnesoid X receptor (FXR)을 직접 억제함으로 써 $A B C B 11$ 의 전사를 방해해 산모의 담즙정체 효과를 나타낼 수 있으며 ${ }^{10)}$, 산모의 증가된 에스트로겐은 태아에서 콜레스테롤 분 비 증가 및 담즙산 생성의 감소를 통해 태아 담석증을 유발할 수 있다 ${ }^{12)}$. 본 증례는 임신성 간내 담즙 정체로 진단된 산모에게서 그 발병 시기에 태아 담석증 또한 동시에 진단됨으로써, 임신성 간내 담즙 정체가 태아 담석증의 위험 인자가 될 수 있음을 임상적으로 보여주는 중요한 증례라고 생각한다. 추후 추가적인 증례 및 그 기 전에 대한 연구가 필요할 것으로 생각된다.

기존의 여러 증례 문헌을 고찰하였을 때, 태아 담석증은 일반적 으로 재태 기간 30 주를 지나 임신 제 3분기에 진단되는 경우가 많 았으며, 무증상 상태로 생후 5개월 이내에 자연적인 호전을 보이 는 경우가 대부분임을 확인할 수 있었다(Table 1). 본 증례 또한 재태 기간 35 주에 진단되어 생후 1 개월에 자연 호전을 보임으로써 이러한 태아 담석증의 임상 양상에 부합하는 소견을 보였다. 태아 담석증은 태아 담도 오니(biliary sludge)에 비해 양호한 예후를 보이는데, 태아 담도 오니는 $18 \%$ 정도가 신생아 시기를 지나서도 지속되는 반면 태아 담석증은 $2 \%$ 정도만이 지속되는 것으로 알려 져 있다 ${ }^{13)}$. 대부분의 태아 담석증은 무증상이며 심각한 합병증을 초래하는 경우는 드물지만, 간혹 소아 또는 성인기의 담석증 및 담 낭염으로 이환되기도 하며 ${ }^{13)}$, 만성 담석증과 동반된 총담관폐쇄, 만성 담낭염으로 신생아기에 복강경 담낭절제술을 시행받은 증례 도 있다 ${ }^{14)}$. 이러한 불량한 예후와 연관되는 요인으로, 태아 담석증 이 재태 주수 26 주 이전에 진단되는 경우, 여아, 산모 또는 가족의 특이 질병력 및 유전 질환, 인종이나 환경 요인, 사회경제적 상태, 불량한 영양, 산모의 탈수 및 감염, 동반된 담관계 기형 등이 알려
져 있다 ${ }^{13)}$.

결론적으로 임신 기간 내 태아 담석증이 발견되었을 때, 발병 시 기, 산모 및 태아의 위험 인자 등을 평가하여 그 예후를 예측해 볼 수 있으며, 일반적으로 재태 주수 30주 이후에 특별한 위험 인자 없이 우연히 발견된 태아 담석증의 경우는 대개 생후 1 세 이전에 자연적으로 호전되는 양상을 보이므로 특별한 치료 없이 연속적 인 복부 초음파 촬영을 시행하며 추적 관찰할 것을 추천한다.

저자들은 재태 주수 35주에 산모의 임신성 간내 담즙정체와 함 께 동반된 태아 담석증을 진단하고 특별한 치료 없이 생후 1 개월 이내에 자연 호전되는 양상을 경험하여 문헌고찰과 함께 보고하 는 바이다.

\section{REFERENCES}

1) Shim JS, Park BC, Hwang YJ, Cho MJ, Seo JY, Jung SJ, et al. A case of neonatal cholelithiasis induced by prolonged lack of enteral feeding and total parenteral nutrition. J Korean Soc Neonatol 2004;11:93-8.

2) Potter HA. Gallbladder disease in young subjects. Surg Gynecol and Obstet 1928;46:795.

3) Beretsky I, Lankin D. Diagnosis of fetal cholelithiasis using real-time high-resolution imaging employing digital detection. J Ultrasound Med 1983;2:381-3.

4) Cancho Candela R, Diaz Gonzalez J, Perandones Fernandez C, Vinuela Rueda B, Relea Sarabia A, Andres de Llano JM. Echogenic material in fetal gallbladder: prenatal diagnosis and postnatal follow-up. An Pediatr (Barc) 2004;61:326-9.

5) Suhag P, Mathur S, Bhardwaj PD. Fetal cholelithiasis: a benign rarity. PJSR 2014;7:63-6.

6) Kiserud T, Gjelland K, Bogno H, Waardal M, Reigstad H, Rosendahl K. Echogenic material in the fetal gallbladder and fetal disease. Ultrasound Obstet Gynecol 1997;10:103-6.

7) Suma V, Marini A, Bucci N, Toffolutti T, Talenti E. Fetal gallstones: sonographic and clinical observations. Ultrasound Obstet Gynecol 1998;12:439-41.

8) Türkmen GG, Timur H, Yilmaz Z, Kirbas A, Daglar K, Tokmak A, et al. Effect of intrahepatic cholestasis of pregnancy on maternal serum screening tests. J Neonatal Perinatal Med 2016;9:411-5.

9) European Association for the Study of the Liver. EASL clinical practice guidelines: management of cholestatic liver diseases. J Hepatol 2009;51:237-67.

10) Dixon PH, Williamson C. The pathophysiology of intrahepatic cholestasis of pregnancy. Clin Res Hepatol Gastroenterol 2016; 40:141-53.

11) Floreani A, Gervasi MT. New insights on intrahepatic chole- 
stasis of pregnancy. Clin Liver Dis 2016;20:177-89.

12) Brown DL, Teele RL, Doubilet PM, DiSalvo DN, Benson CB, Van Alstyne GA. Echogenic material in the fetal gallbladder: sonographic and clinical observations. Radiology 1992;182:736.

13) Troyano-Luque J, Padilla-Perez A, Martinez-Wallin I, Alvarez de la Rosa M, Mastrolia SA, Trujillo JL, et al. Short and long term outcomes associated with fetal cholelithiasis: a report of two cases with antenatal diagnosis and postnatal follow-up. Case Rep Obstet Gynecol 2014;2014:714271. doi: 10.1155/2014/ 714271.

14) Gertner M, Farmer D. Laparoscopic cholecystectomy in a 16day-old infant with chronic cholelithiasis. J Pediatr Surg 2004;39:17-9.
15) Petrikovsky B, Klein V, Holsten N. Sludge in fetal gallbladder: natural history and neonatal outcome. Br J Radiol 1996;69: 1017-8.

16) Stringer MD, Lim P, Cave M, Martinez D, Lilford RJ. Fetal gallstones. J Pediatr Surg 1996;31:1589-91.

17) Nishi T. Ultrasonographic diagnosis of fetal cholelithiasis. J Obstet Gynaecol Res 1997;23:251-4.

18) Hertzberg BS, Kliewer MA. Fetal gallstones in a contracted gallbladder: potential to simulate hepatic or peritoneal calcification. J Ultrasound Med 1998;17:667-70.

19) Munjuluri N, Elgharaby N, Acolet D, Kadir RA. Fetal gallstones. Fetal Diagn Ther 2005;20:241-3.

20) Triunfo S, Rosati P, Ferrara P, Gatto A, Scambia G. Fetal cholelithiasis: a diagnostic update and a literature review. Clin Med Insights Case Rep 2013;6:153-8. 